\title{
KLASIFIKASI JENIS TANAMAN PADA HALAMAN BANGUNAN SUCI DALAM RELIEF CANDI BOROBUDUR
}

\author{
Dian Eka Puspitasari \\ Balai konservasi Borobudur \\ dee.puspitasari@gmail.com
}

\begin{abstract}
ABSTRAK
Jenis tanaman pada relief merupakan salah satu objek penelitian yang cukup menarik, karena tanaman digambarkan dengan sangat detail pada relief. Relief tanaman menjadi salah satu latar belakang dari konteks cerita dalam relief sehingga dapat menggambarkan konteks lingkungan dengan tepat. Perbedaan konteks lingkungan hutan, tepi laut, sungai, permukiman maupun kebun terlihat dengan jelas pada panil-panil relief candi. Salah satu konteks lingkungan adalah konteks lingkungan halaman pada bangunan suci/candi. Bangunan suci/candi beberapa kali muncul dalam konteks cerita relief dimana beberapa penggambaran memiliki latar belakang tanaman. Kajian jenis tanaman yang terdapat pada halaman bangunan suci/candi dalam konteks cerita relief serta fungsinya dalam lanskap menjadi topik dalam penelitian ini. Penelitian difokuskan pada relief Karmawibhangga, Lalitavistara, dan Jataka-Avadana yang berada di dinding utama lorong I. Hasil penelitian menemukan 20 jenis tanaman dari 33 penggambaran tanaman pada halaman bangunan suci/candi dengan 11 jenis tanaman yang berfungsi sebagai peneduh, 8 jenis tanaman yang berfungsi sebagai penghias, dan satu jenis tanaman yang berfungsi sebagai peneduh dan penghias.
\end{abstract}

Kata Kunci: Jenis tanaman; bangunan candi; bangunan suci; tanaman halaman

\begin{abstract}
The types of plants in the reliefs are one of the objects of research that are quite interesting, because the plants are described in great detail in the reliefs. The relief of plants is one of the backgrounds of the story context in the relief so that it can accurately describe the environmental context. The different environmental contexts of forest, seaside, rivers, settlements and gardens are clearly visible on the relief panels of the temple. One of the environmental contexts is the environmental context of the courtyard in the sacred building/temple. Sacred buildings/temples appear several times in the context of relief stories where some depictions have a plant background. The study of the types of plants found in the courtyards of sacred buildings/temples in the context of relief stories and their functions in the landscape is the topic of this research. The research focused on the reliefs of Karmawibhangga, Lalitavistara, and Jataka-Avadana which are located on the main wall of hallway I. The results of the study found 20 types of plants from 33 depictions of plants in the courtyard of the sacred building/temple with 11 types of plants that function as shade, 8 types of plants that function as a decoration, and one type of plant that serves as a shade and decoration.
\end{abstract}

Keywords: Type of plant; temple building; sacred building; yard plant 



\section{PENDAHULUAN}

Candi Borobudur merupakan candi Buddha peninggalan wangsa Syailendra yang sudah berumur ratusan tahun dan memiliki nilai karya seni cukup tinggi. Bangunan dibangun sejak abad VIII-IX Masehi dengan menggunakan batu andesit yang disusun sedemikian rupa di atas bukit tanpa menggunakan perekat dan hanya menggunakan sistem sambungan batu yang saling terkait serta dapat dibongkar pasang (knock down) (Puspitasari, Setyawan dan Rini, 2010; Suhartono dkk., 2017, hal. 83). Bangunan candi merupakan perpaduan dari stupa, candi dan gunung, sehingga bentuk Candi Borobudur berupa piramida berundak 10 lantai yang pada bagian lantai teratas terdapat stupa besar masif dengan dikelilingi 72 stupa kecil berongga (Puspitasari, Setyawan dan Rini, 2010). Oleh karena itu sejak tahun 1991, Candi Borobudur Bersama Candi Mendut dan Candi Pawon yang merupakan candi Buddha dan masih dalam satu kawasan menjadi warisan dunia (world heritage) nomor C 592 dengan nama Borobudur Temple Compounds (Committee, 2012, hal. 113).

W.F. Stutterheim membagi Candi Borobudur menjadi tiga tingkatan spiritual, yaitu kamadhatu, rupadhatu, dan arupadhatu (Santiko, 2012, hal. 3). Kamadhatu merupakan tingkatan terbawah yang terdiri dari dua lantai kaki terbawah termasuk kaki tertutup dibawahnya yang berarti kawasan nafsu (Sedyawati, 2011, hal. 37). Rupadhatu merupakan bagian tengah dari lantai ketiga sampai lantai tujuh yang berarti kawasan yang terikat pada wujud-wujud karena merupakan dunia antara (Puspitasari, Setyawan dan Rini, 2010, hal. 28; Sedyawati, 2011, hal. 37). Tiga lantai teratas yang berbentuk lingkaran merupakan bagian arupadhatu, yang merepresentasikan dunia tak berwujud dimana nafsu duniawi telah ditinggalkan (Puspitasari, Setyawan dan Rini, 2010, hal. 35).

Relief merupakan gambar yang dipahatkan pada bagian tubuh candi. Relief yang menghiasi Candi Borobudur tersebut terdiri dari relief hias dan relief naratif/cerita. Relief hias merupakan ornamen/dekorasi yang hanya berfungsi memperindah bangunan candi, sedangkan relief naratif merupakan relief yang mempunyai cerita tertentu baik dengan tokoh manusia, hewan maupun kedewataan (Munandar, 2018, hal. 19). Total keseluruhan panil ada 2672 panil relief yang terdiri dari 1460 relief naratif dan 1212 relief hias (Soekmono, 1976, hal. 20).

Relief naratif terdapat pada tingkatan kamadhatu dan rupadhatu. Pada tingkatan kamadhatu, terdapat Relief Karmawibhangga yang berisikan hukum sebab akibat dengan jumlah panil 160 (Soekmono, 1976, hal. 21). Tingkatan rupadhatu terdapat relief Lalitavistara, Jataka-Avadana, Gandawyuha, dan Bhadracari. Relief Lalitavistara menceritakan perjalanan Siddhartha dalam mencapai kebuddhaan (Soekmono, 1976, hal. 21). Relief ᄀJataka mengenai reinkarnasi berulang sang Buddha sebelum menjadi Pangeran Siddhartha dalam melakukan kebaikan, sedangkan Avadana memiliki cerita yang hampir mirip dengan Jataka namun tokohnya bukan sang Buddha melainkan tokoh-tokoh legendaris (Soekmono, 1976, hal. 26). Relief Gandawyuha bercerita mengenai kisah pengembaraan Sudhana dalam mencapai kebijaksanaan tertinggi yang sempurna (Soekmono, 1976, hal. 30). Relief Bhadracari merupakan kisah dimana Sudhana sudah memperoleh kebijaksanaan sempurna yang tertinggi. Jumlah panil dan letak masing-masing relief pada tingkatan rupadhatu dapat dilihat pada tabel di bawah ini: 
Tabel 1. Relief Naratif pada Tingkatan Rupadhatu

\begin{tabular}{|l|l|l|c|}
\hline \multicolumn{1}{|c|}{ LANTAI } & \multicolumn{1}{|c|}{ POSISI RELIEF } & \multicolumn{1}{|c|}{ NAMA RELIEF } & $\begin{array}{c}\text { JUMLAH } \\
\text { PANIL }\end{array}$ \\
\hline Lantai III & Dinding utama atas & Lalitavistara & 120 \\
\hline & Dinding utama bawah & Jataka/Avadana & 120 \\
\hline & Dinding pagar langkan (balustrade) atas & Jataka/Avadana & 372 \\
\hline & $\begin{array}{l}\text { Dinding pagar langkan (balustrade) } \\
\text { bawah }\end{array}$ & Jataka/Avadana & 128 \\
\hline Lantai IV & Dinding utama & Gandawyuha & 128 \\
\hline & Dinding pagar langkan (balustrade) & Jataka/Avadana & 100 \\
\hline Lantai V & Dinding utama & Gandawyuha & 88 \\
\hline & Dinding pagar langkan (balustrade) & Gandawyuha & 88 \\
\hline Lantai VI & Dinding utama & Gandawyuha & 84 \\
\hline & Dinding pagar langkan (balustrade) & Gandawyuha/Bhadracari & 72 \\
\hline
\end{tabular}

Relief-relief yang ada pada dinding Candi Borobudur tersebut dipahat secara detail oleh para silpin (seniman pahat) baik relief hias maupun relief naratif (Munandar, 2018, hal. 15). Relief tersebut berfungsi untuk menyampaikan ajaran agama melalui bahasa rupa dan memperindah bangunan, namun relief juga berfungsi sebagai media yang memudahkan penyampaian ajaran keagamaan serta membuat cerita-cerita keagamaan tersebut menjadi abadi karena terpahat pada batu (Munandar, 2018, hal. 39). Oleh karena itu, banyak penggambaran relief terpahat secara detail dan merupakan karya seni yang bernilai tinggi, terutama relief yang ada di Candi Borobudur. Hal tersebut dapat terlihat dari detail pahatan yang mampu menggambarkan manusia, bangunan, tanaman, hewan, dan obyek lain, sehingga bentuk-bentuk yang dipahatkan dapat dipahami orang awam, sebelum dapat mengetahui cerita yang dimaksud.

Bentuk penggambaran pada relief Candi Borobudur yang sering dibahas salah satunya adalah flora atau tanaman. Jenis-jenis tanaman pada relief candi ini pernah dibahas oleh peneliti-peneliti terdahulu seperti Cammerloher (1931), Steinmann (1934), dan van den Brink (1931) walaupun mereka tidak membahas semua jenis tanaman yang ada pada relief. Menurut Cammerloher (1931, 143), gambar relief tanaman yang terpahat di Candi Borobudur tidak mengandung gambar skematis ataupun fantastis karena penggambarannya sangat akurat. Ia berpendapat bahwa tanaman yang dipahatkan pada relief berhubungan dengan ajaran Buddha sekaligus menggambarkan kehidupan keseharian manusia. Pendapat Cammerloher (1931) tersebut didukung oleh Steinmann (1934, 582) yang mengidentifikasikn jenis tanaman yang terdapat pada relief Candi Borobudur juga mencakup tanaman obat dan budidaya, sedangkan Brink (1931, 181-86) dalam tulisannya lebih banyak mereview dan mengoreksi dari karya Cammerloher (1931).

Penelitian lain mengenai jenis tanaman juga dibahas oleh Hari Setyawan dkk. (2018) namun dengan fokus penelitian pada relief Karmawibhangga dan relief Lalitavistara serta relief yang ada pada Candi Mendut. Penelitian yang dilakukannya didasarkan pada data prasasti tertentu dan naskah sastra Jawa kuna. Selain pengidentifikasikan jenis tanaman, Hari Setyawan dkk. (2018) juga menelaah keterkaitan antara jenis tanaman dengan konteks lingkungannya. Penelitian tanaman pada relief Candi Borobudur juga dilengkapi oleh Metusala dkk. (2020) yang secara lebih detail membahas jenis tanaman yang ada pada relief Lalitavistara. Penelitian Metusala dkk. (2020) menemukan setidaknya 63 jenis tanaman pada relief Lalitavistara tersebut. 
Relief tanaman tidak hanya digunakan untuk membangun latar atau konteks lingkungan tempat adegan yang dikisahkan terjadi, akan tetapi, relief tanaman memiliki fungsi lain, yaitu sebagai pembatas adegan atau penyekat (Sarwono, 1985, hal. 14-15). Hal ini dikarenakan dalam satu panil cerita relief, terkadang ada lebih dari satu adegan cerita. Untuk membatasi antar adegan tersebut salah satunya digunakan relief tanaman. Selain dua fungsi tersebut, relief tanaman juga berfungsi dekoratif untuk mengisi bagian yang kosong pada panil relief sehingga dalam satu relief cerita utuh, tidak ada bagian yang terasa kosong (Stutterheim, 1989, hal. ix). Tanaman yang tergambar pada relief Candi Borobudur dapat ditemukan dalam sejumlah lingkungan, baik permukiman, istana, taman, asrama atau pertapaan, bangunan suci, maupun pada bentang alam tertentu, antara lain persawahan, perkebunan, dan perairan (Hari Setyawan dkk., 2018, hal. 112). Pada konteks lingkungan tertentu tentunya keberadaan tanaman memiliki fungsi masing-masing yang kemudian sangat mempengaruhi lanskap yang terbentuk. Dengan demikian, keberadaan tanaman dapat dikatakan merupakan salah satu elemen dalam lanskap.

Tanaman sebagai elemen lanskap memiliki berbagai fungsi yaitu dapat mengontrol pandangan, membatasi fisik, mengendalikan iklim, mencegah erosi, sebagai habitat atau tempat tinggal satwa/hewan, serta menambah nilai estetis (Hakim dan Utomo, 2004). Fungsi tanaman sebagai elemen lanskap tentu akan ditentukan pula oleh karakter tanaman tersebut, seperti bentuk tajuk, daun, bunga, buah, ranting maupun cabang, serta habitus yang berbedabeda satu dengan yang lainnya. Oleh karena itu dengan adanya perbedaan karakter pada tanaman, setiap tanaman juga dapat difungsikan sebagai tanaman penutup tanah, pelindung, tanaman pagar, pengarah jalan, tanaman merambat, serta sebagai penutup/tanaman tabir (Lestari dan Kencana, 2015).

Identifikasi bangunan suci atau candi pada relief Candi Borobudur sudah pernah dilakukan oleh beberapa peneliti sebelumnya. Krom dalam bukunya "Archaeological Description" volume kedua pernah menyebutkan sepintas mengenai bangunan-bangunan yang tergambar pada relief candi Borobudur terutama berupa kuil (Krom, 1927, hal. 216). Atmadi (1979) dalam disertasinya juga membahas mengenai bangunan-bangunan yang ada pada relief Candi Borobudur dengan menitikberatkan pada bangunan candi. Hasil penelitiannya merupakan patokan perancangan candi dengan menganalisis dari gambar yang ada pada relief. Selain itu, Atmadi (1979) juga sedikit membahas mengenai pola halaman yaitu bagaimana letak pagar, gapura dan bangunan yang tergambar dalam relief di Candi Borobudur. Adanya beberapa penelitian terdahulu, dapat menjadi acuan pada penelitian yang dilakukan ini. Jenis tanaman maupun konteks lingkungan bangunan suci yang pernah diidentifikasi oleh para peneliti terdahulu dapat menjadi panduan awal, tetapi digunakan dengan kritis. Artinya, hasil kajian terdahulu dapat saja diterima ataupun tidak, karena adanya perbedaan pendapat ataupun ketidaksesuain dalam sudut pandang.

Tulisan ini akan membahas mengenai jenis tanaman sebagai elemen lanksap yang ditemukan pada konteks halaman bangunan suci atau candi sebagaimana dipahatkan pada relief Candi Borobudur, yang selama ini belum mendapat perhatian secara khusus dalam penelitian-penelitian sebelumnya. Pembahasan akan lebih ditujukan untuk menjawab pertanyaan, apakah fungsi tanaman-tanaman yang terdapat pada lingkungan bangunan suci atau candi? Sebelum dapat menentukan fungsinya, terlebih dahulu perlu dilakukan identifikasi konteks bangunan suci dengan jenis tanaman yang terdapat pada lingkungan tersebut.

Penelitian ini bermanfaat untuk mengenalkan jenis-jenis tanaman dan fungsinya yang terdapat di sekitar bangunan suci atau candi serta potensinya berdasar cerita relief. Dengan demikian penelitian ini diharapkan juga dapat menambah referensi mengenai jenis tanaman yang ada pada relief. Selain itu, hasil penelitian dapat dimanfaatkan sebagai panduan pemilihan jenis tanaman untuk penataan lanskap di lingkungan sekitar bangunan suci atau candi terutama di kawasan Borobudur. 


\section{FOKUS PENELITIAN DAN METODE}

Penelitian difokuskan pada relief Karmawibhangga, Lalitavistara, dan relief JatakaAvadana. Relief Jataka-Avadana yang dimaksud adalah hanya relief yang berada di dinding lorong I lantai III dan berada di bawah relief Lalitavistara, sedangkan relief Jataka-Avadana yang berada di dinding pagar langkan (balustrade) lorong I lantai III dan dinding pagar langkan lorong II lantai IV tidak termasuk dalam penelitian karena banyak bagian relief yang hilang/rusak. Total jumlah relief yang diteliti ada 400 panil relief, terdiri atas 160 panil relief Karmawibhangga, 120 panil relief Lalitavistara, dan 120 panil relief Jataka-Avadana.

Data dasar relief yang akan dianalisis berupa foto-foto yang diambil oleh van Erp. Data foto-foto ini dipilih, karena gambar relief masih terlihat dengan jelas. Selain itu, foto panil relief Karmawibhangga yang paling lengkap adalah foto-foto yang diambil pada masa van Erp. Setelah itu, pemilihan data dilakukan untuk memisahkan gambar relief yang sesuai dengan fokus penelitian yaitu relief yang menggambarkan bangunan suci dengan tanaman sebagai latar belakang halamannya.

Dalam melakukan pengelompokan dan analisis data, penelitian ini menggunakan bantuan Software adobe photoshop dan atlas.ti. Software adobe photoshop digunakan untuk memperjelas dan mempertajam bagian gambar yang dipilih sesuai dengan fokus penelitian. Dengan demikian, bagian gambar yang tidak sesuai akan dibuat tidak terlalu mencolok. Setelah melakukan pemilihan semua relief yang menjadi objek penelitian, gambar-gambar relief tersebut dianalisa dan dikelompokkan menggunakan software atlas.ti untuk mencari hubungan antar gambar yang telah dikodifikasi.

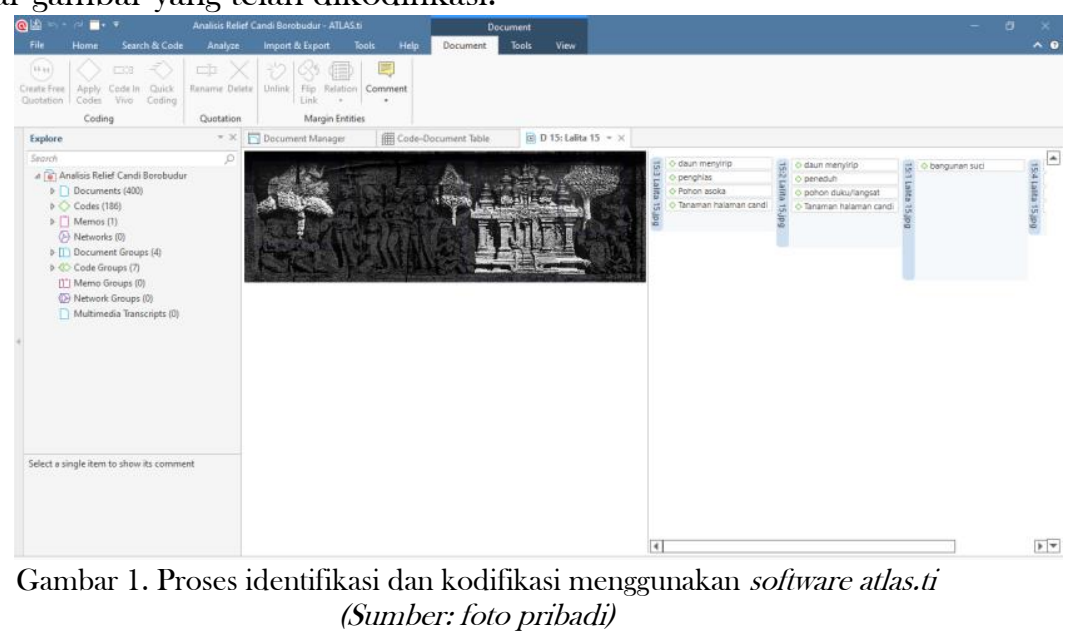

Untuk penomoran relief digunakan kode yang diterapkan oleh van Erp. Kode 0-IV digunakan untuk relief yang terletak pada dinding lorong. Kode IB-IV digunakan untuk relief yang letaknya di dinding pagar langkan (balustrade). Penomoran relief sesuai dengan arah jarum jam/pradaksina dengan menggunakan angka arab (1,2,3, dst). Kode "a" digunakan untuk letak relief yang ada di atas, sedangkan kode "b" digunakan untuk relief yang terletak pada dinding bagian bawah. Dengan demikian, penomoran untuk relief Karmawibhangga menggunakan kode 0-1, 0-2, 0-3, dst sampai panil ke 160. Untuk relief lalitavistara menggunkan kode Ia-1, Ia-2, Ia-3, dst sampai panil ke 120. Relief Jataka-Avadana yang berada pada bagian bawah relief Lalitaistara menggunakan kode Ib-1, Ib-2, Ib-3, dst sampai panil nomor 120 .

Dalam melakukan identifikasi mengenai jenis tanaman, ada beberapa macam cara yang dapat dilakukan. Salah satunya adalah dengan melakukan identifikasi jenis tanaman dengan pendekatan morfologi, yaitu dengan cara melihat bentuk karakteristik tanaman dari 
penggambaran bentuk daun, bunga, batang, maupun buahnya. Selain itu, setting lingkungan yang digambarkan pada relief juga bisa menjadi kunci mengenai habitat tanaman tersebut, apakah tanaman liar seperti di hutan, atau tanaman di pantai, tanaman yang dipelihara di halaman ataupun tanaman budidaya di kebun. Hal ini karena menurut Kusen (1984-1985) dalam Hari Setyawan dkk. (2018), pada relief terdapat bentuk-bentuk tertentu seperti rumah, pohon, maupun sungai untuk menggambarkan situasi serta kondisi yang diharapkan menggambarkan keadaan dalam cerita bersangkutan. Dengan demikian, penggambaran tanaman akan dapat diketahui bagaimana kondisi di sekitarnya jika dilakukan analisis secara kontekstual menurut Hari Setyawan dkk. (2018) sehingga seperti apa lahan ataupun lingkungan tempat tanaman tersebut tumbuh dapat diidentifikasi.

\section{ANALISA DAN PEMBAHASAN}

Relief pada Candi Borobudur menunjukkan bahwa masyarakat Jawa, terutama pada masa pembangunan Candi Borobudur, memiliki pengetahuan yang luas mengenai lingkungan alamnya, termasuk kegunaan dan bahaya dari tumbuhan. Karena itu, jenis tanaman yang terpahat di candi tidak hanya menggambaran kehidupan keagamaan, tetapi juga berhubungan dengan keseharian manusia (Cammerloher, 1931, hal. 143). Selain itu, penggambaran jenis tanaman juga berhubunngan dengan konteks lingkungan yang menjadi latar belakangnya. Hari Setyawan dkk. (2018) menyebutkan bahwa konteks lingkungan yang menjadi latar belakang antara lain suatu permukiman, istana, tempat peribadatan, taman, asrama, sawah, hutan, tegalan, telaga/danau/sungai, ataupun pertapaan. Walaupun dalam penelitiannya masih terbatas pada relief Karmawibhangga dan Lalitavistara, penelitian yang dilakukan Hari Setyawan dkk. (2018) tersebut dapat menunjukkan situasi yang tergambar di masa lalu. Penelitian tersebut menunjukkan bahwa relief cerita di Candi Borobudur merupakan kisah agama Buddha yang diambil dari sutra-sutra, tetapi pemahat relief melukiskan adegan itu dalam situasi lingkungan kehidupan di Jawa pada masa itu. (Hari Setyawan dkk., 2018).

Selain melihat setting lingkungan yang menjadi latar belakang, dalam proses identifikasi juga mengutamakan pendekatan morfologi tanaman. Akan tetapi, penggambaran relief tanaman yang ada terkadang sangat detail sehingga menunjukkan bentuk daun dan buah secara jelas tetapi ada juga yang digambarkan secara umum sehingga kurang jelas jenis tanamannya. Oleh karena itulah ada perbedaan pendapat tergantung dari sudut pandang peneliti. Seperti contohnya pandangan Brink (1931) mengenai jenis tanaman alocasia yang disebut oleh Cammerloher sebagai tanaman bira/sente (Alocasia macrorrhiza L). Brink (1931) juga menemukan jenis tanaman bambu yang tidak ditemukan oleh Cammerloher, dengan melihat gambar relief yang terdapat pada karya Pleyte (1901. Selain itu, menurut pendapat Brink, tanaman yang disebut padi oleh Cammerloher merupakan tanaman jewawut (Setaria italica) karena Brink berpendapat bahwa jewawut adalah biji-bijian yang tertua di daerah Jawa. Dengan demikian, perbedaan pendapat tersebut tentulah dapat menjadi pembahasan lebih lanjut maupun upaya memperkaya jenis tanaman yang ada dalam relief.

Dalam pembahasan ini, jenis tanaman yang diidentifikasi adalah tanaman halaman yang menjadi latar belakang pada bangunan suci atau candi dalam relief Candi Borobudur. Bangunan suci atau candi yang tergambar pada relief Candi Borobudur dapat dengan mudah dikenali. Bentuk bangunan biasanya digambarkan tampak depan ataupun tampak samping dengan adanya dekorasi yang khas seperti adanya bentuk stupa ataupun keben. Selain dari bentuknya, dapat pula dilihat dari penggambaran latar belakang dengan adanya sekelompok orang yang sedang melakukan pemujaan di depan bangunan tersebut. Bentuk bangunannya pun tidak hanya setipe namun ada berbagai tipe bangunan suci atau candi yang dapat ditemukan pada relief Candi Borobudur.

Jumlah bangunan suci atau candi yang ditemukan pada panil relief Karmawibhangga, Lalitavistara, dan relief Jataka-Avadana ada 48 unit. Dari 48 bentuk bangunan suci atau candi 
tersebut hanya ada 24 bangunan suci atau candi yang diidentifikasi memiliki latar belakang halaman dengan berbagai jenis tanaman. Bangunan suci yang memiliki latar belakang halaman dengan berbagai jenis tanaman dapat dilihat dari tabel di bawah ini.

Tabel 2. Panil Relief Bangunan Suci atau Candi dengan Latar Belakang Halaman

\begin{tabular}{|l|l|l|c|}
\hline NO & \multicolumn{1}{|c|}{ RELIEF } & \multicolumn{1}{|c|}{ PANIL NOMOR } & JUMLAH \\
\hline 1 & Karmawibhangga & $\begin{array}{l}\text { 0-24, 0-31, 0-90, 0-100, 0-140, 0-141, 0-143, 0- } \\
147, \text { dan 0-155 }\end{array}$ & 9 \\
\hline 2 & Lalitavistara & Ia-6, Ia-15, Ia-18, Ia-23, Ia-81, Ia-109, dan Ia-112. & 7 \\
\hline 3 & Jataka-Avadana & $\begin{array}{l}\text { Ib-25, Ib-27, Ib-79, Ib-85, Ib-87, Ib-91, Ib-96, dan } \\
\text { Ib-107. }\end{array}$ & 8 \\
\hline
\end{tabular}

Halaman bangunan suci/candi merupakan salah satu konteks lingkungan yang tergambar dalam relief Candi Borobudur. Pemahatan jenis tanaman yang ada tentunya dimaksudkan untuk menciptakan suasana lingkungan yang diinginkan sesuai dengan konteks cerita (Hari Setyawan dkk., 2018). Beberapa karakter jenis tanaman mungkin bisa saja merupakan bagian dari naskah cerita yang menjadi acuan, akan tetapi tidak semuanya merupakan bagian dari cerita. Meskipun demikian, tentu saja para silpin/pemahat relief akan mengambil jenis tanaman yang terdapat di lingkungan mereka dan sesuai untuk membentuk suasana dalam cerita. Pemilihan jenis tanaman yang dipahatkan juga tidak sembarang, tetapi disesuaikan dengan kebutuhan untuk latar belakang cerita. Karakter jenis tanaman, habitat, serta fungsi tanaman yang dipilih oleh para silpin/pemahat menjadi syarat dalam pemilihan jenis tanaman.

Dari hasil identifikasi, tanaman pada halaman candi tersebut memiliki fungsi lanskap sebagai peneduh maupun sebagai penghias. Tanaman peneduh merupakan tanaman yang berfungsi untuk melindungi benda ataupun orang yang berada dibawahnya dari sinar matahari, angin maupun air hujan (Dwiyani, 2013, hal. vii). Dengan demikian tanaman yang berfungsi sebagai peneduh terlihat dari tajuk yang digambarkan dalam cerita relief yaitu bentuk tajuknya melebar dan terkadang digambarkan menaungi objek yang ada di bawahnya. Tanaman yang berfungsi sebagai penghias merupakan tanaman yang memiliki nilai estetis, dapat dilihat dari karakteristik tanamannya misalnya bentuk daun, ranting, batang yang unik maupun tanaman yang berbunga indah. Tanaman penghias digunakan untuk memberikan keindahan serta dapat dinikmati secara visual karena memiliki bentuk serta warna yang indah (Widyastuti, 2018, hal. 2)

Hasil identifikasi penggambaran tanaman halaman bangunan suci atau candi dari 24 unit bangunan suci atau candi yang memiliki latar belakang halaman dengan tanaman pada relief Karmawibhangga, Lalitavistara, dan Jataka/Avadana, seluruhnya ada 47 tanaman. Tidak semua tanaman dapat teridentifikasi jenisnya. Tanaman yang dapat diidentifikasi berjumlah 33 tanaman dengan 20 macam jenis tanaman, sedangkan yang belum dapat diidentifikasi sekitar 14 tanaman. Tanaman yang belum dapat teridentifikasi tersebut terdapat pada relief Karmawibhangga dengan nomor panil 0-90, 0-140, 0-143, 0-147, Jataka/ Avandana Ia-109, Ib-27, Ib-85, Ib-91, dan Ib-96 serta dua relief tanaman rusak yang terdapat pada panil nomor Ib-107.

Beberapa tanaman yang tergambar pada relief belum dapat teridentifikasi karena beberapa hal, antara lain gambar yang terpahat tidak jelas, aus, ataupun rusak, tidak memiliki karakteristik yang khas/gambar tidak terlalu detail, atau jenis tanaman mitologi seperti tanaman Kalpataru atau Kalpavrikșa (Kalpawreksa) yang merupakan tanaman tempat seseorang memohonkan sesuatu permintaan atau keinginan (wishing tree) (Ferrari dan Dahnhardt, 2016, hal. 10). Kalpataru merupakan pohon keabadian yang tumbuh di taman istana (Nandan van) Dewa Indra dan merupakan symbol kelimpahan, kemakmuran, 
kegembiraan, dan kebahagiaan serta dapat mengabulkan keinginan semua orang (Upadhyaya, 1964, hal. 17). Beberapa tanaman yang diidentifikasi sebagai pohon Kalpataru atau Kalpavrkșa (Kalpawreksa) antara lain adalah asam jawa (Tamarindus indica L., kelapa (Cocos nucifera L.), srigading (Nyctanthes arbor-tristis), randu alas (Bombax ceiba) parijata/dadap (Erythrina variegata), banyan (Ficus benghalensis), mahua (Madhuca longifolia), shami (Prosopis cineraria), mentega india (Diploknema butyracea), dan mulberry (Morus nigra tree) ((Ferrari dan Dahnhardt, 2016, hal. 14; Raut, Nayak dan Gotmare, 2017, hal. 1211; Abhinav dkk., 2018, hal. 183; Joshi, Chaudhary dan Rawat, 2018, hal. 135; Jayakumar, 2019, hal. 90; Kumar dkk., 2020, hal. 1849).

Di bawah ini merupakan hasil identifikasi 20 jenis tanaman halaman candi yang terdapat pada relief Karmawibhangga, Lalitavistara, dan Jataka/Avadana.

Tabel 3. Jenis Tanaman pada Halaman Candi dalam Relief Candi Borobudur

\begin{tabular}{|c|c|c|c|c|c|c|}
\hline \multirow[b]{2}{*}{ NO } & \multirow[b]{2}{*}{ Jenis Tanaman } & \multirow[b]{2}{*}{ Relief } & \multirow[b]{2}{*}{ Panil No } & \multicolumn{2}{|c|}{ Fungsi Tanaman } & \multirow{2}{*}{$\begin{array}{l}\text { Frekuensi } \\
\text { kemuncul } \\
\text { an dalam } \\
\text { relief }\end{array}$} \\
\hline & & & & Peneduh & Penghias & \\
\hline 1 & $\begin{array}{l}\text { Asoka (Saraca } \\
\text { asoca (Roxb.) J.J. } \\
\text { de Wilde) }\end{array}$ & Lalitavistara & la-15 & & $\sqrt{ }$ & 1 \\
\hline 2 & $\begin{array}{l}\text { Angsana } \\
\text { (Pterocarpus } \\
\text { indicus WILLD) }\end{array}$ & Lalitavistara & $\begin{array}{l}\text { la-23 (ada } 2 \\
\text { pohon) }\end{array}$ & $\sqrt{ }$ & & 2 \\
\hline 3 & $\begin{array}{l}\text { Beringin cina } \\
\text { (Ficus microcarpa } \\
\text { L.f) }\end{array}$ & $\begin{array}{l}\text { Jataka- } \\
\text { Avadana (b) }\end{array}$ & lb-25 & $\sqrt{ }$ & & 1 \\
\hline 4 & $\begin{array}{l}\text { Bodhi (Ficus } \\
\text { religiosa L) }\end{array}$ & $\begin{array}{l}\text { Karmawibhang } \\
\text { ga, Lalitavistara }\end{array}$ & $\begin{array}{l}0-31,0-147 \\
\text { la-6, lb-79 }\end{array}$ & $\sqrt{ }$ & & 4 \\
\hline 5 & $\begin{array}{l}\text { Dadap (Erythrina } \\
\text { variegata } \mathrm{L} \text { ) }\end{array}$ & $\begin{array}{l}\text { Karmawibhang } \\
\text { ga, Lalitavistara }\end{array}$ & $0-155$ & $\sqrt{ }$ & $\sqrt{ }$ & 1 \\
\hline 6 & $\begin{array}{l}\text { Damar (Agathis } \\
\text { dammara) }\end{array}$ & $\begin{array}{l}\text { Jataka- } \\
\text { Avadana (b) }\end{array}$ & lb-87 & & $\sqrt{ }$ & 1 \\
\hline 7 & $\begin{array}{l}\text { Duku (Lansium } \\
\text { parasiticum } \\
\text { (Osbeck) Sahni \& } \\
\text { Bennet) }\end{array}$ & Lalitavistara & la-15 & $\sqrt{ }$ & & 1 \\
\hline 8 & $\begin{array}{l}\text { Jambu air } \\
\text { (Syzygium } \\
\text { aqueum (Burm.f.) } \\
\text { Alston) }\end{array}$ & $\begin{array}{l}\text { Karmawibhang } \\
\text { ga, Lalitavistara }\end{array}$ & $0-24$, la-15 & $\sqrt{ }$ & & 2 \\
\hline 9 & $\begin{array}{l}\text { Karet merah/karet } \\
\text { kebo (Ficus } \\
\text { elastica Roxb. Ex } \\
\text { Hornem) }\end{array}$ & $\begin{array}{l}\text { Jataka- } \\
\text { Avadana (b) }\end{array}$ & $\mathrm{lb}-107$ & $\sqrt{ }$ & & 1 \\
\hline 10 & $\begin{array}{l}\text { Keben } \\
\text { (Barringtonia } \\
\text { asiatica (L.) Kurz) }\end{array}$ & $\begin{array}{l}\text { Karmawibhang } \\
\text { ga, Lalitavistara }\end{array}$ & $\begin{array}{l}0-31,0-100 \\
\text { la-112 }\end{array}$ & $\sqrt{ }$ & & 3 \\
\hline 11 & $\begin{array}{l}\text { Kecubung (Datura } \\
\text { metel) }\end{array}$ & $\begin{array}{l}\text { Karmawibhang } \\
\text { ga, Lalitavistara }\end{array}$ & $0-31$ & & $\sqrt{ }$ & 1 \\
\hline 12 & $\begin{array}{l}\text { Kelapa (Cocos } \\
\text { nucifera L) }\end{array}$ & Lalitavistara & la-23, la-81 & & $\sqrt{ }$ & 2 \\
\hline
\end{tabular}




\begin{tabular}{|c|c|c|c|c|c|c|}
\hline 13 & $\begin{array}{l}\text { Ketapang } \\
\text { (Terminalia } \\
\text { catappa L) }\end{array}$ & $\begin{array}{l}\text { Karmawibhang } \\
\text { ga, Lalitavistara }\end{array}$ & $0-90$, la-109 & $\sqrt{ }$ & & 2 \\
\hline 14 & $\begin{array}{l}\text { Lontar/siwalan } \\
\text { (Borassus } \\
\text { flabellifer L) }\end{array}$ & $\begin{array}{l}\text { Jataka- } \\
\text { Avadana (b) }\end{array}$ & $\mathrm{lb}-27$ & & $\sqrt{ }$ & 1 \\
\hline 15 & $\begin{array}{l}\text { Lotus (Nelumbium } \\
\text { Nelumbo/Nelumb } \\
\text { o nucifera Gaertn) }\end{array}$ & $\begin{array}{l}\text { Karmawibhang } \\
\text { ga }\end{array}$ & $0-147$ & & $\sqrt{ }$ & 1 \\
\hline 16 & $\begin{array}{l}\text { Mangga } \\
\text { (Mangifera indica) }\end{array}$ & $\begin{array}{l}\text { Karmawibhang } \\
\text { ga, Lalitavistara }\end{array}$ & $\begin{array}{l}0-24 \text { (ada } 2 \\
\text { pohon), } 0-141, \\
0-147, \text { la-109 }\end{array}$ & $\sqrt{ }$ & & 5 \\
\hline 17 & $\begin{array}{l}\text { Nyamplung } \\
\text { (Calophyllum } \\
\text { inophyllum L) }\end{array}$ & $\begin{array}{l}\text { Karmawibhang } \\
\text { ga }\end{array}$ & $0-24$ & $\sqrt{ }$ & & 1 \\
\hline 18 & $\begin{array}{l}\text { Pisang (Musa } \\
\text { paradisiaca) }\end{array}$ & Lalitavistara & la-109 & & $\sqrt{ }$ & 1 \\
\hline 19 & $\begin{array}{l}\text { Sukun } \\
\text { (Artocarpus altilis } \\
\text { (Parkinson) } \\
\text { Fosberg) }\end{array}$ & Lalitavistara & la-18 & $\sqrt{ }$ & & 1 \\
\hline 20 & $\begin{array}{l}\text { Teratai } \\
\text { (Nymphaea) }\end{array}$ & $\begin{array}{l}\text { Karmawibhang } \\
\text { ga }\end{array}$ & $0-147$ & & $\sqrt{ }$ & 1 \\
\hline
\end{tabular}

relief.

Berikut adalah gambaran lebih rinci mengenai identifikasi tanaman pada setiap

\section{Relief Karmawibhangga}

1. Panil nomor 0-24: Dilihat dari morfologi tanaman, pada panil ini terdapat empat tanaman dengan yaitu pohon mangga (Mangifera indica) yang berada di sebelah kiri bangunan suci/candi terdapat, Serta pohon nyamplung (Calophyllum inophyllum L), pohon jambu air (Syzygium aqueum (Burm.f.) Alston), dan pohon mangga (Mangifera indica) disebelah kanan bangunan suci/candi. Keempat tanaman tersebut memiliki fungsi sebagai peneduh, terlihat dari bentuk tajuk yang lebar serta menaungi orang-orang yang berada di bawahnya.

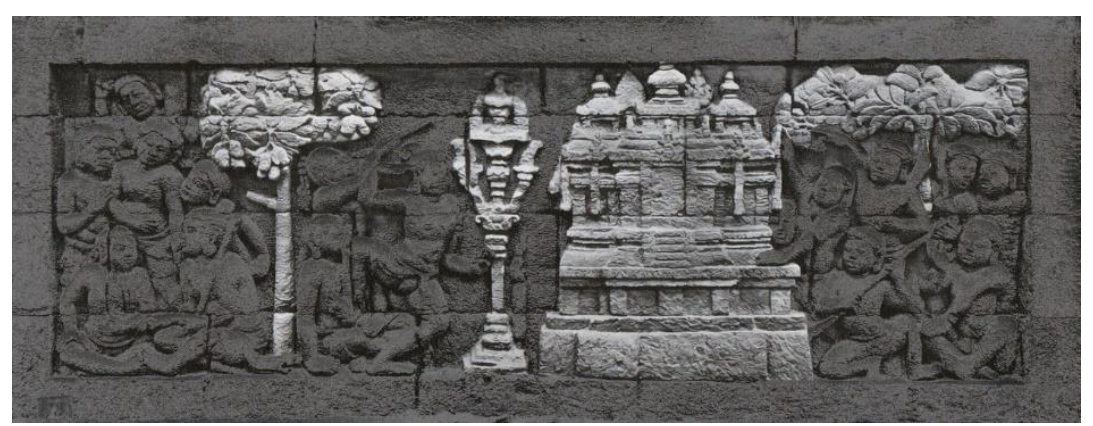

Gambar 2. Panil nomor 0-24 relief Karmawibhangga

(Sumber : repro foto van Erp dengan editan pribadi)

2. Panil nomor 0-31 (lihat Gambar 2): Pada panil ini terdapat empat tanaman dan 2 bangunan. Tanaman yang merupakan tanaman halaman pada bangunan suci hanya tiga macam, yaitu di sebelah kiri terdapat pohon bodhi (Ficus religiosa L) yang berfungsi sebagai peneduh dan tanaman kecubung (Datura metel) yang berfungsi sebagai 
penghias. Satu pohon lainnya adalah pohon ketapang ( Terminalia catappa L) yang juga berfungsi sebagai peneduh di sebelah kanan bangunan.

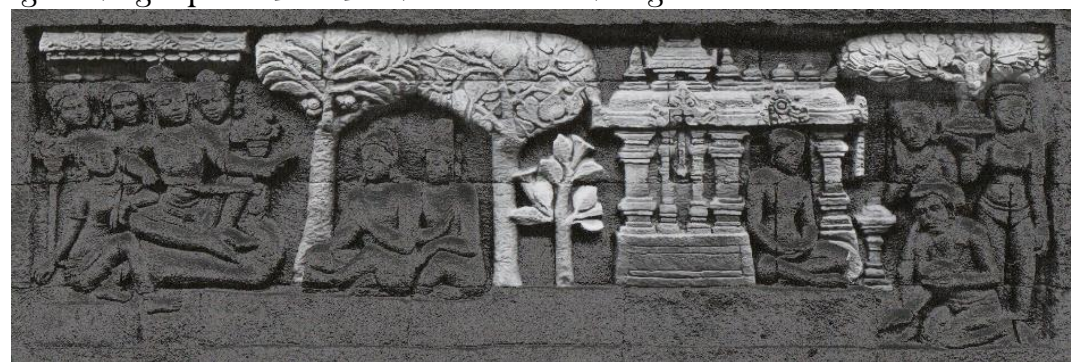

Gambar 3. Panil nomor 0-31 relief Karmawibhangga

(Sumber : repro foto van Erp dengan editan pribadi)

3. Panil nomor 90: Pada panil ini juga terdapat beberapa jenis tanaman, namun yang merupakan tanaman halaman candi ada dua macam. Tanaman berdaun bulat pipih diidentifikasi sebagai tanaman ketapang ( Terminalia catappa L) yang berfungsi sebagai peneduh, sedangkan tanaman yang berada di sebelah kanan bangunan dengan daun bulat belum dapat diidentifikasi. Memperhatikan letak dan karakternya dengan tajuk melebar, pohon ini berfungsi pula sebagai peneduh.

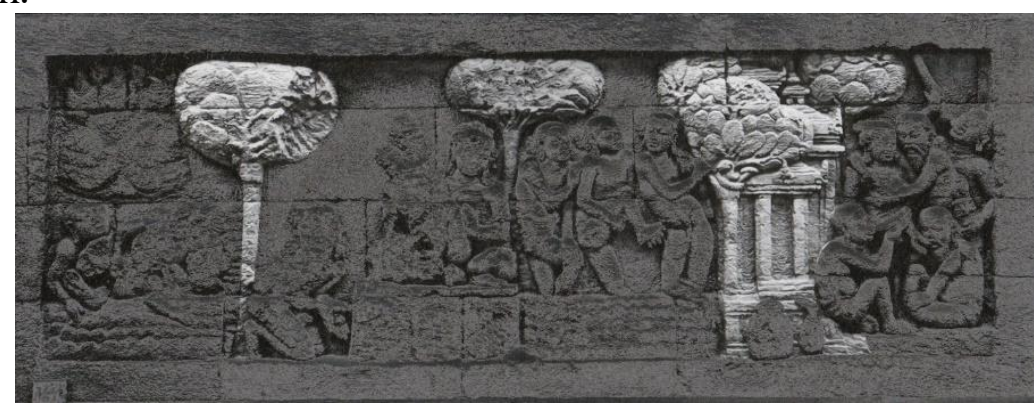

Gambar 4. Panil nomor 0-90 relief Karmawibhangga

(Sumber: repro foto van Erp dengan editan pribadi)

4. Panil nomor 100: Terdapat satu tanaman yang diidentifikasi sebagai tanaman halaman candi dari beberapa tanaman yang tergambar pada panil relief. Dari hasil identifikasi, berdasarkan bentuk daunnya yang bulat pipih dan terlihat ada detail buah, tanaman tersebut merupakan pohon keben (Barringtonia asiatica (L.) Kurz. Tanaman tersebut berada di sebelah kanan bangunan dan berfungsi sebagai peneduh.

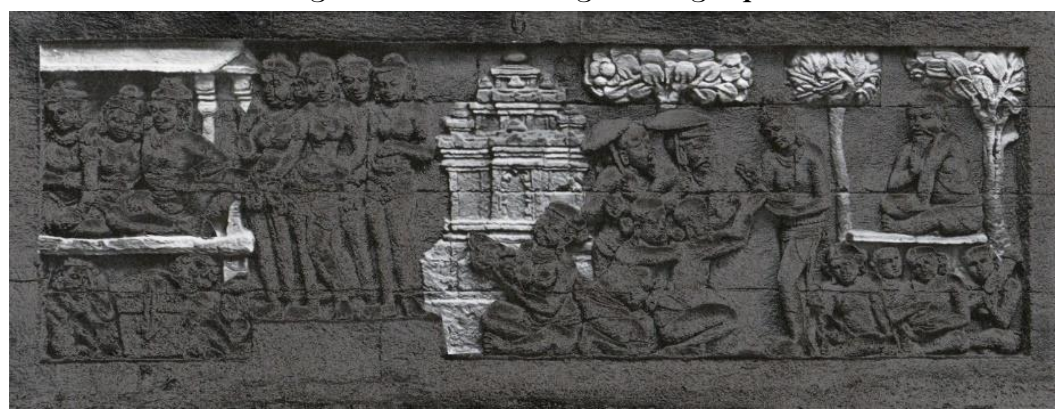

Gambar 5. Panil nomor 0-100 relief Karmawibhangga (Sumber : repro foto van Erp dengan editan pribadi) 
5. Panil nomor 140 (lihat Gambar 3): Pada panil ini terdapat satu jenis tanaman, apabila dilihat dari bentuk tanaman merupakan tanaman yang berfungsi sebagai penghias serta tanaman yang berfungsi untuk mengabulkan permintaan (wishing tree). Hal ini karena dalam penggambarannya terlihat seperti ada bendera doa yang digantungkan pada tanaman tersebut. Jenis tanaman ini belum dapat teridentifikasi.

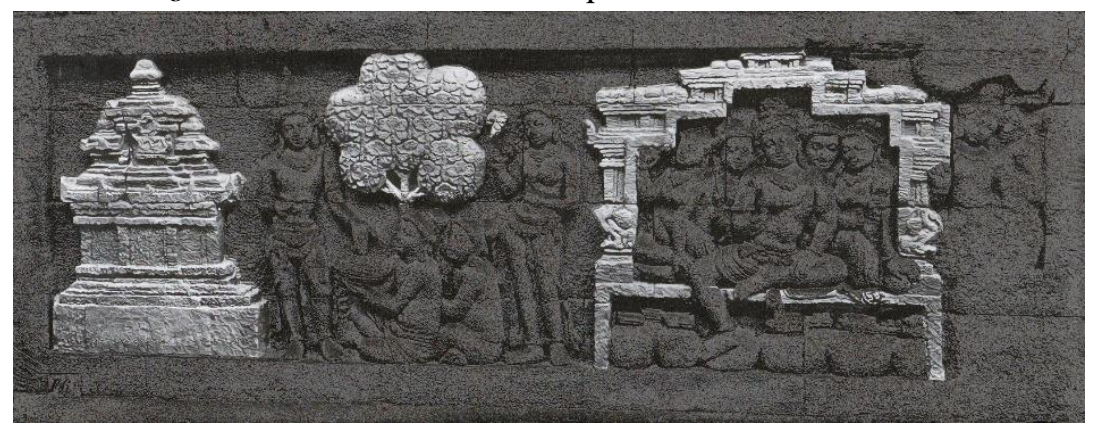

Gambar 6. Panil nomor 0-140 relief Karmawibhangga

(Sumber : repro foto van Erp dengan editan pribadi)

6. Panil nomor 141: Pada panil ini terdapat satu jenis tanaman pada sebelah kiri bangunan suci/candi. Tanaman yang berfungsi sebagai peneduh teridentifikasi sebagai pohon mangga (Mangifera indica) dilihat dari bentuk daun dan buah yang tergambar.

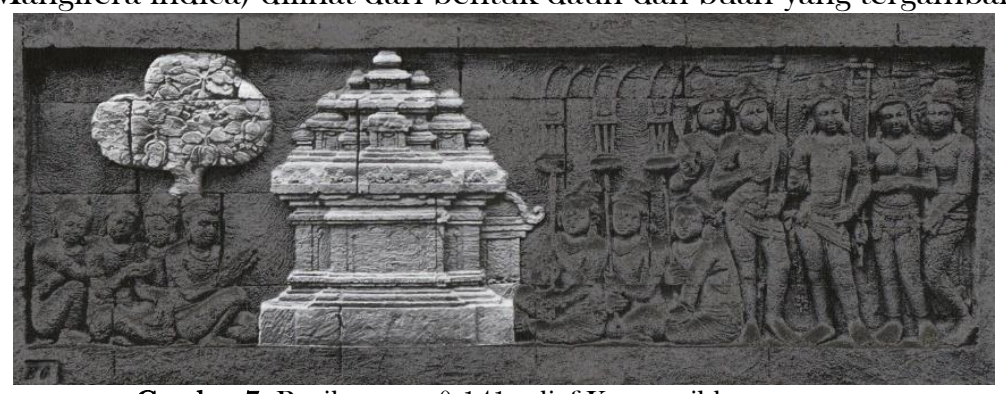

Gambar 7. Panil nomor 0-141 relief Karmawibhangga

(Sumber: repro foto van Erp dengan editan pribadi)

7. Panil nomor 143 (lihat Gambar 8): Tanaman yang teridentifikasi sebagai tanaman halaman candi/bangunan suci pada panil ini berada di bagian paling kanan. Jenis tanaman belum dapat teridentifikasi. Jenis tanaman merupakan tanaman untuk mengabulkan permintaan (wishing tree) yang berfungsi sebagai penghias juga.

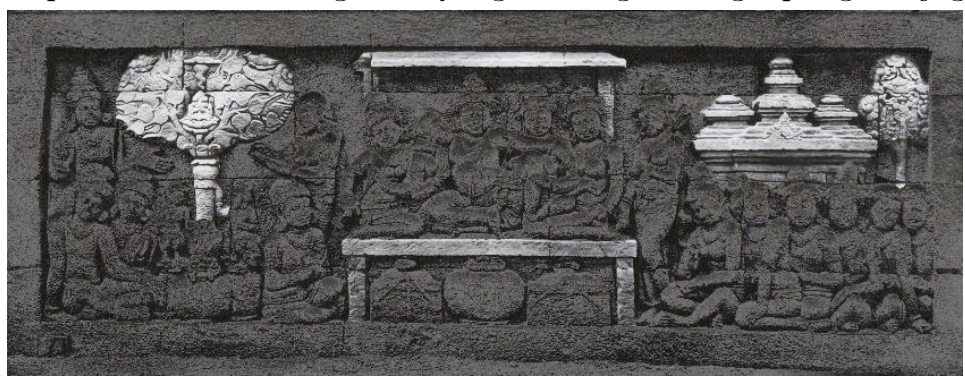

Gambar 8. Panil nomor 0-143 relief Karmawibhangga (Sumber: repro foto van Erp dengan editan pribadi) 
8. Panil nomor 147 (lihat Gambar 9): Pada panil ini terdapat beberapa jenis tanaman halaman candi/bangunan suci, namun hanya empat tanaman yang berhasil diidentifikasi. Tanaman tersebut dua diantaranya merupakan tanaman air yang dapat berfungsi sebagai penghias, yaitu tanaman teratai (Nymphaea) dan tanaman lotus (Nelumbo nucifera Gaertn). Tanaman lain yang dapat teridentifikasi adalah pohon mangga (Mangifera indica) yang terlihat dari bentuk daun dan buahnya serta pohon bodhi (Ficus religiosa L) yang berada di bagian paling kanan. Pohon mangga dan pohon bodhi dapat berfungsi sebagai tanaman peneduh, meski demikian, dalam penggambaran relief tersebut, tanaman bodhi digambarkan juga berfungsi sebagai tanaman Kalpataru/Kalpavṛsșa/Kalpawreksa atau tanaman untuk mengabulkan permintaan (wishing tree). Hal itu tampak dari adanya ciri yang tidak ditemukan secara alami, antara lain bentuk seperti payung di tengah rerimbunan daun dan di bawahnya terdapat sejumlah wadah penampung.

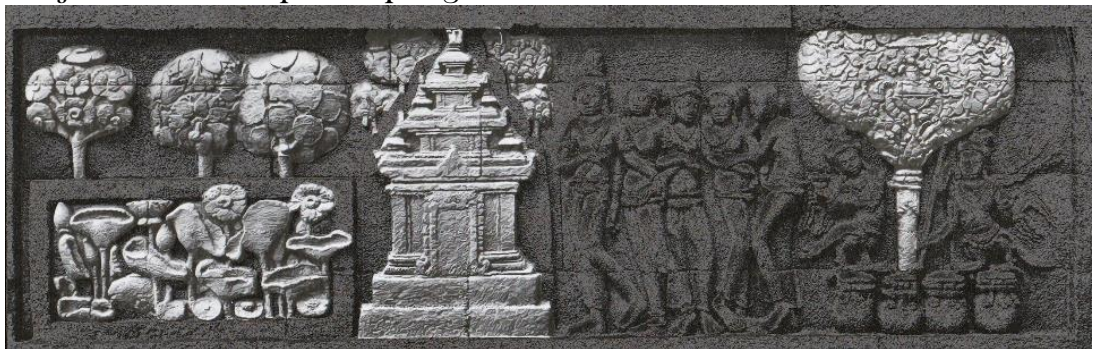

Gambar 9. Panil nomor 0-147 relief Karmawibhangga

(Sumber: repro foto van Erp dengan editan pribadi)

9. Panil nomor 155 (lihat Gambar 10): Pada panil ini terdapat satu jenis tanaman yang merupakan tanaman Kalpataru/Kalpavṛkșa/Kalpawreksa atau tanaman untuk mengabulkan permintaan (wishing tree). Dilihat dari bentuk daun yang seperti jantung dan memiliki bunga, tanaman tersebut diidentifikasi sebagai pohon dadap (Erythrina variegata $\mathrm{L}$ ) yang berfungsi sebagai peneduh karena memiliki tajuk yang lebar. Akan tetapi tanaman ini juga dapat berfungsi sebagai penghias karena memiliki bunga yang indah.

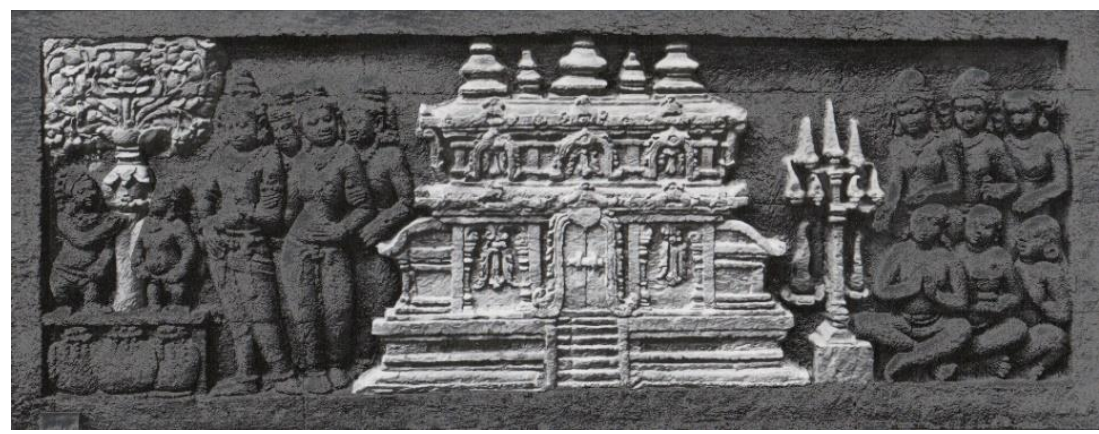

Gambar 10. Panil nomor 0-155 relief Karmawibhangga (Sumber: repro foto van Erp dengan editan pribadi)

\section{Relief Lalitavistara}

1. Panil nomor Ia-6 : Tanaman pada panil ini berada pada bagian sebelah kiri, yang diidentifikasi sebagai tanaman peneduh. Dilihat dari bentuk daunnya yang seperti jantung, tanaman ini dididentifikasi sebagai pohon bodhi (Ficus religiosa L). 


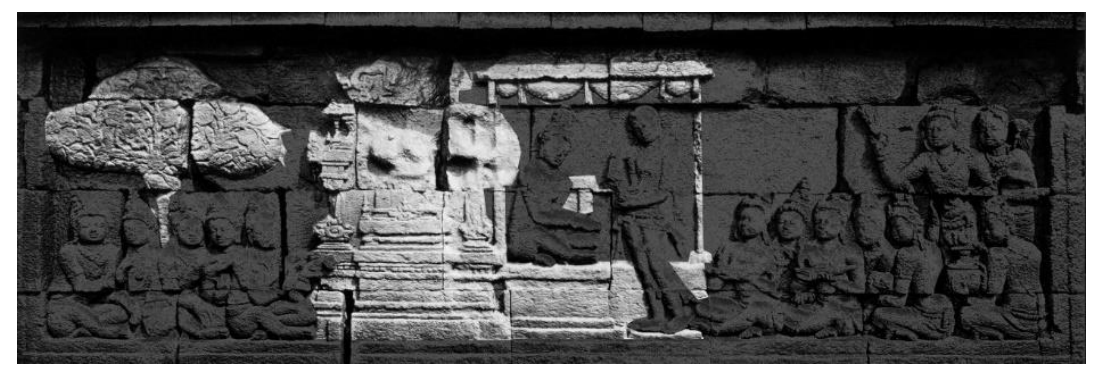

Gambar 11. Panil nomor Ia-6 relief Lalitavistara

(Sumber: repro foto van Erp dengan editan pribadi)

2. 2. Panil nomor Ia-15 (lihat Gambar 7): Pada panil ini terdapat tiga tanaman yang merupakan tanaman halaman candi/bangunan suci pada panil ini. Tanaman pada bagian kiri diidentifikasi sebagai tanaman peneduh yaitu pohon duku (Lansium parasiticum (Osbeck) Sahni \& Bennet karena terdapat buah yang bergerombol kecilkecil. Tanaman pada bagian tengah diidentifikasi sebagai pohon asoka (Saraca asoca (Roxb.) J.J. de Wilde) dan berfungsi sebagai penghias karena digambarkan bertajuk kerucut. Tanaman yang berada paling kanan diidentifikasi sebagai pohon jambu air (Syzygium aqueum (Burm.f.) Alston) dan memiliki fungsi sebagai peneduh.

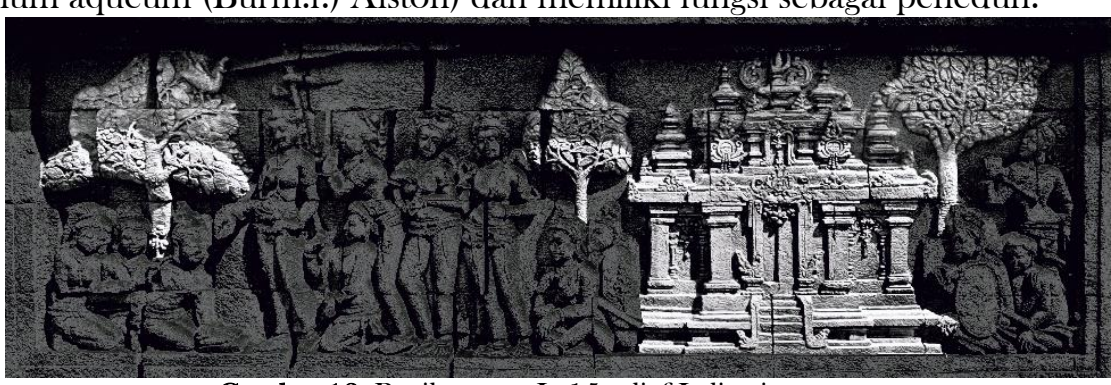

Gambar 12. Panil nomor Ia-15 relief Lalitavistara

(Sumber: repro foto van Erp dengan editan pribadi)

3. Panil nomor Ia-18: Pada panil ini yang termasuk tanaman halaman candi merupakan tanaman sebelah kanan yang berada dekat dengan bangunan suci/candi. Tanaman yang berfugsi sebagai peneduh tersebut diidentifikasi sebagai pohon sukun (Artocarpus altilis (Parkinson) Fosberg).

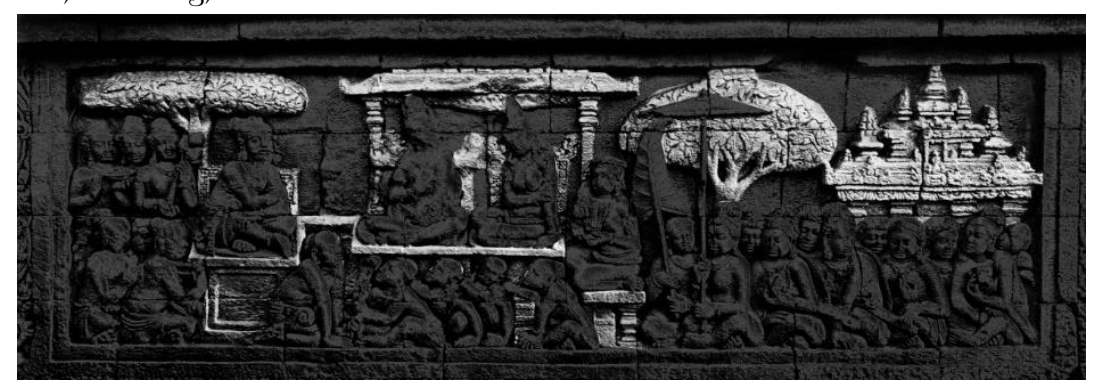

Gambar 13. Panil nomor Ia-18 relief Lalitavistara

(Sumber: repro foto van Erp dengan editan pribadi)

4. Panil nomor Ia-23: Pada panil ini terdapat tiga tanaman. Tanaman pertama dan kedua yang berada di sebelah kiri dan tengah merupakan tanaman peneduh dan diidentifikasi sebagai pohon angsana (Pterocarpus indicus WILLD). Tanaman yang berada di 
sebelah kanan dan dekat dengan bangunan suci diidentifikasi sebagai pohon kelapa (Cocos nucifera L) serta berfungsi sebagai tanaman penghias.

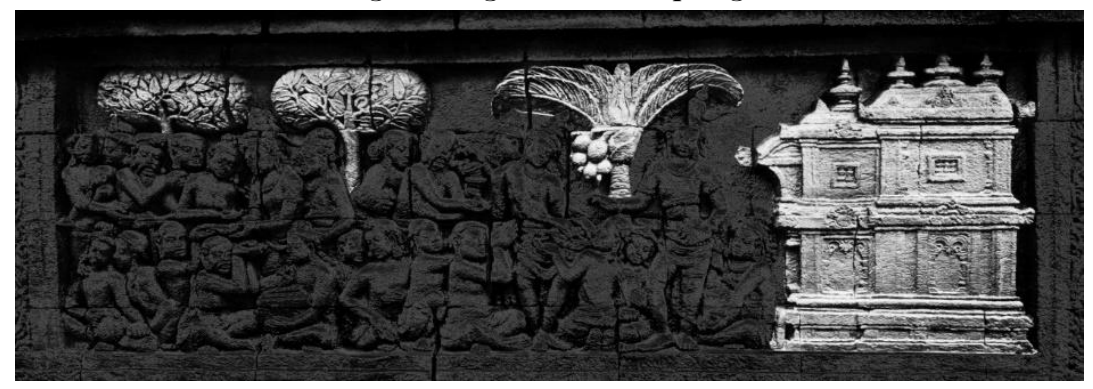

Gambar 14. Panil nomor Ia-23 relief Lalitavistara

(Sumber: repro foto van Erp dengan editan pribadi)

5. Panil nomor Ia-81 : Tanaman halaman candi/bangunan suci pada panil ini terdapat di sebelah kanan bangunan. Dari bentuk daun dan buahnya, tanaman ini merupakan pohon kelapa (Cocos nucifera L ) dan berfungsi sebagai penghias.

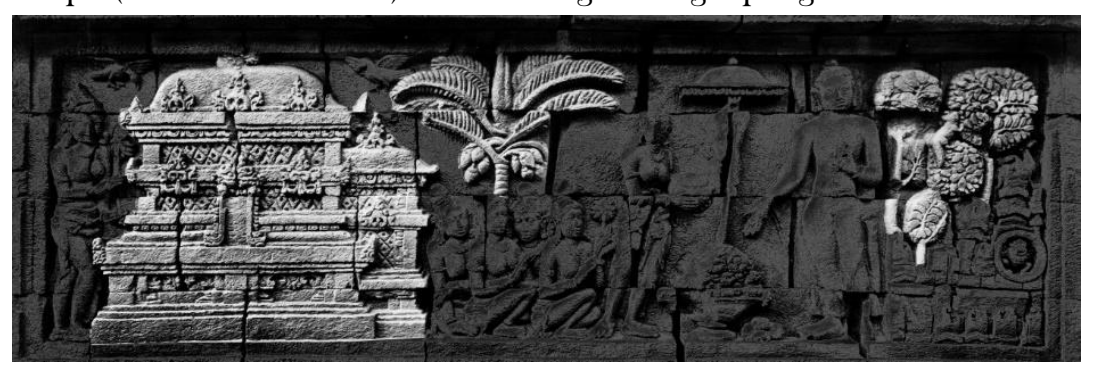

Gambar 15. Panil nomor Ia-81 relief Lalitavistara

(Sumber: repro foto van Erp dengan editan pribadi)

6. Panil nomor Ia-109 (lihat Gambar 8): Pada panil ini terdapat empat jenis tanaman yang merupakan tanaman halaman candi/bangunan suci. Tanaman jenis pertama merupakan pohon pisang (Musa paradisiaca) yang berfungsi sebagai penghias. Tanaman jenis kedua adalah pohon ketapang (Terminalia catappa L) yang berfungsi sebagai peneduh. Tanaman ketiga yang berada di sebelah kiri bangunan belum dapat diidentifikasi dan berfungsi sebagai peneduh. Tanaman keempat berada di sebelah kanan bangunan merupakan pohon mangga (Mangifera indica) dan berfungsi sebagai peneduh.

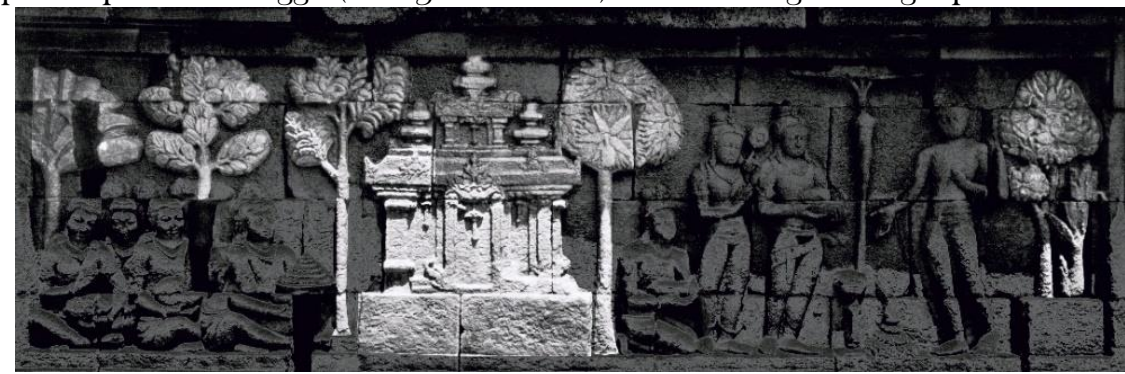

Gambar 16. Panil nomor Ia-109 relief Lalitavistara

(Sumber: repro foto van Erp dengan editan pribadi)

7. Panil nomor Ia-112: Tanaman halaman candi/bangunan suci pada panil ini hanya ada satu jenis yang berada di samping kanan bangunan. Tanaman tersebut diidentifikasi sebagai pohon keben (Barringtonia asiatica (L.) Kurz) dan berfungsi sebagai peneduh. 


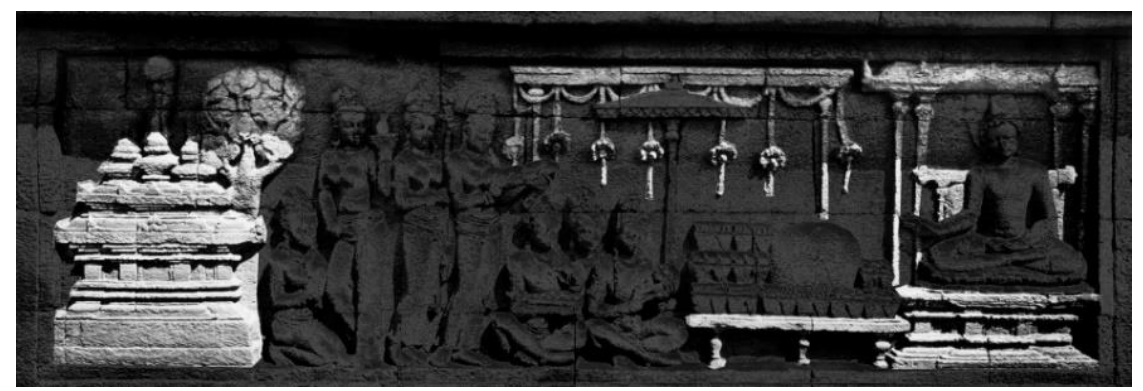

Gambar 17. Panil nomor Ia-112 relief Lalitavistara

(Sumber: repro foto van Erp dengan editan pribadi)

\section{ReliefJataka/Avadana}

1. Panil nomor Ib-25 (lihat Gambar 9): Tanaman yang merupakan tanaman halaman candi/bangunan suci pada panil ini terlihat berada di dalam pagar. Tanaman tersebut diidentifikasi sebagai pohon beringin cina (Ficus microcarpa L.f) yang berfungsi sebagai peneduh.

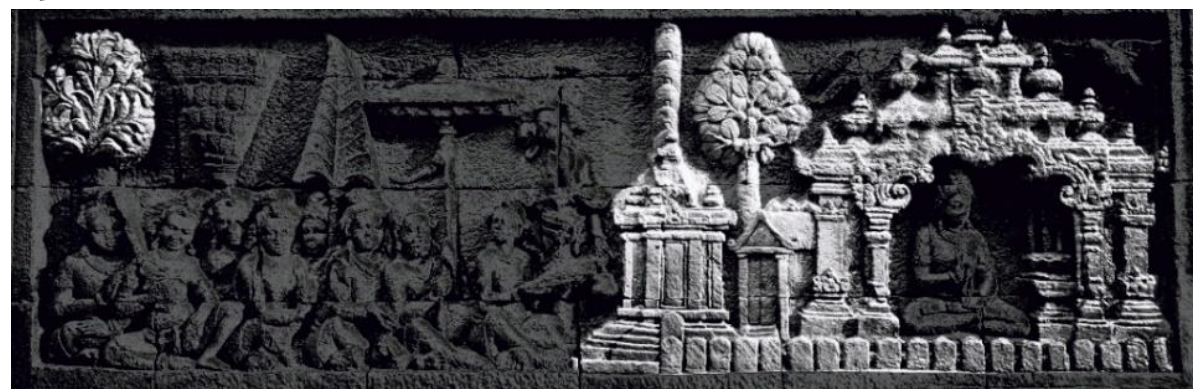

Gambar 18. Panil nomor Ib-25 relief Jataka-Avadana

(Sumber: repro foto van Erp dengan editan pribadi)

2. Panil nomor Ia-27: Pada panil ini terdapat dua jenis tanaman yang termasuk tanaman halaman candi/bangunan. Tanaman pertama berfungsi sebagai penghias dan diidentifikasi sebagai pohon lontar/siwalan (Borassus flabellifer L). Tanaman kedua berfungsi sebagai peneduh namun belum dapat diketahui jenis tanamannya.

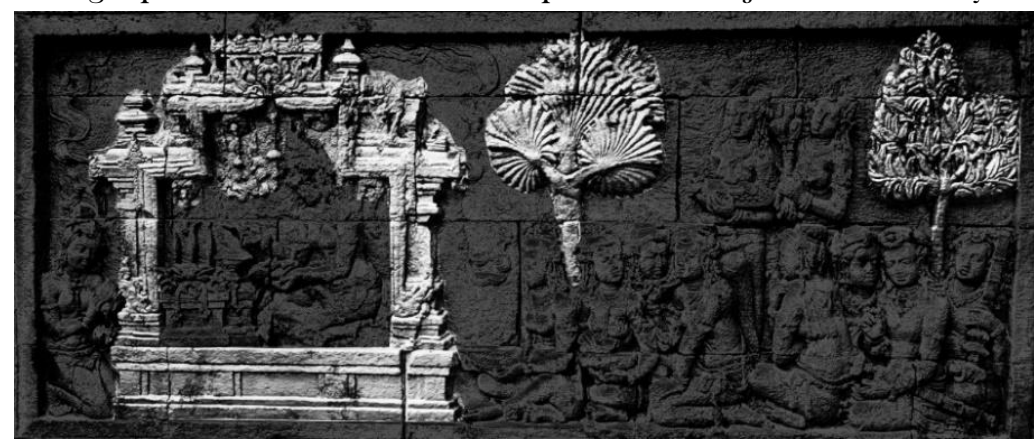

Gambar 13. Panil nomor Ib-27 relief Jataka-Avadana

(Sumber: repro foto van Erp dengan editan pribadi)

3. Panil nomor Ib-79: Tanaman halaman candi/bangunan suci pada panil ini terdapat pada pagar. Tanaman tersebut diidentifikasi sebagai pohon bodhi (Ficus religiosa L) dan berfungsi sebagai peneduh. 


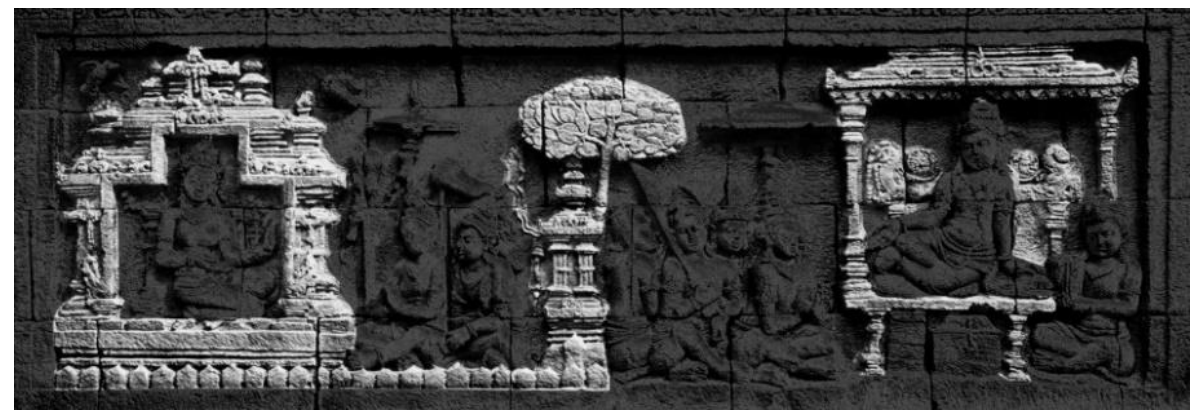

Gambar 20. Panil nomor Ib-79 relief Jataka-Avadana

(Sumber: repro foto van Erp dengan editan pribadi)

4. Panil nomor Ib-85: Jenis tanaman pada panil ini merupakan tanaman Kalpataru/Kalpavṛkșa/Kalpawreksa yang berfungsi sebagai penghias dan belum dapat teridentifikasi jenisnya.

5. Panil nomor Ib-87: Pada panil ini, tanaman halaman candi/bangunan suci digambarkan di dalam pagar halaman. Tanaman tersebut diidentifikasi sebagai pohon damar (Agathis dammara) dan berfungsi sebagai penghias.

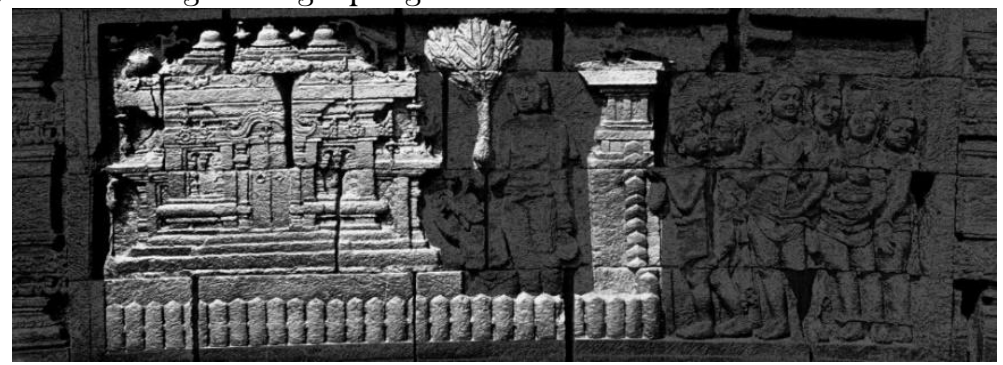

Gambar 21. Panil nomor Ib-87 relief Jataka-Avadana

(Sumber: repro foto van Erp dengan editan pribadi)

6. Panil nomor Ib-91: Pada panil ini tanaman halaman candi/bangunan suci belum dapat diidentifikasi jenisnya. Tanaman tersebut berfungsi sebagai peneduh.

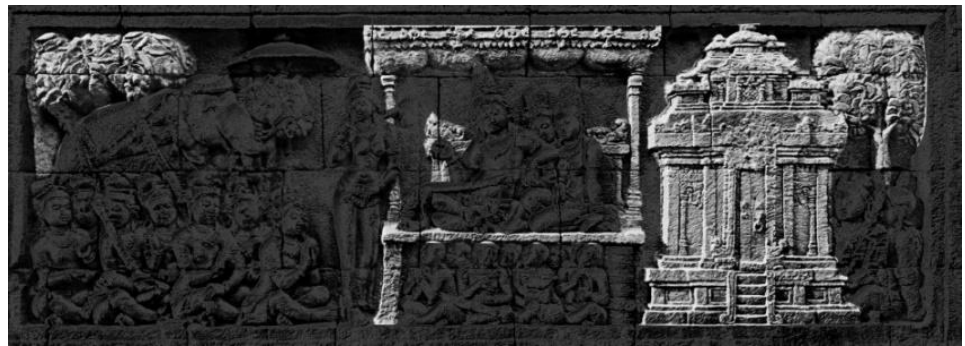

Gambar 22. Panil nomor Ib-91 relief Jataka-Avadana

(Sumber: repro foto van Erp dengan editan pribadi)

7. Panil nomor Ib-96 (lihat Gambar 10): Pada panil ini tanaman halaman candi/bangunan suci juga belum dapat diidentifikasi jenisnya. Tanaman tersebut berfungsi sebagai peneduh. 


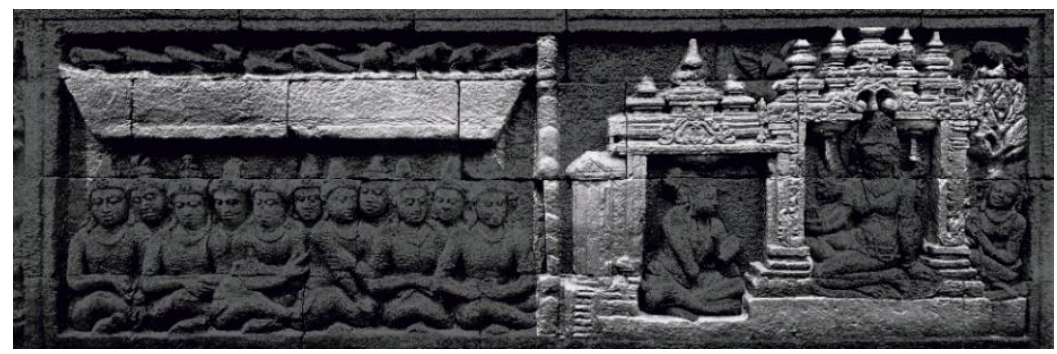

Gambar 23. Panil nomor Ib-96 relief Jataka-Avadana

(Sumber: repro foto van Erp dengan editan pribadi)

8. Panil nomor Ib-107: Tanaman yang merupakan tanaman halaman candi/bangunan suci pada panil ini ada tiga pohon. Dua jenis tanaman tidak dapat diketahui jenisnya karena kondisi relief yang rusak. Tanaman yang dapat diketahui jenisnya diidentifikasi sebagai pohon karet merah/karet kebo (Ficus elastica Roxb. Ex Hornem) yang berfungsi sebagai peneduh.

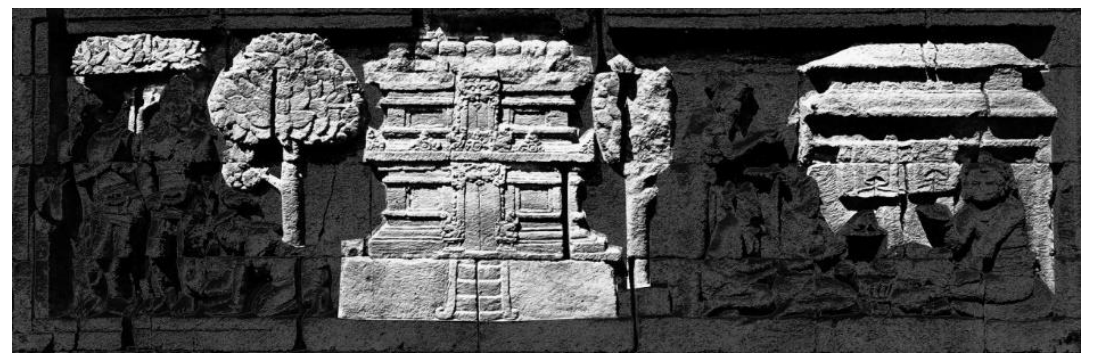

Gambar 4. Panil nomor Ib-107 relief Jataka-Avadana

(Sumber: repro foto van Erp dengan editan pribadi)

Tanaman-tanaman yang teridentifikasi sebagai tanaman pada halaman bangunan candi/bangunan suci tersebut ada yang merupakan tanaman sakral/memiliki makna religius bagi agama Buddha. Beberapa jenis tanaman sakral tersebut antara lain:

1. Asoka (Saraca asoca (Roxb.) J.J. de Wilde). Pohon ini merupakan pohon sakral bagi umat Buddha. Beberapa literatur dan relief menggambarkan kelahiran Sang Buddha dimana Ratu Maya sedang memegang cabang pohon Asoka saat hendak melahirkan (Bidari, 1996, hal. 16).

2. Bodhi (Ficus religiosa L), dikenal juga sebagai pohon Pipal. Pohon Bodhi dianggap sakral karena Sang Buddha mendapat pencerahan di bawah pohon tersebut (Cunningham, 1892, hal. 30; Upadhyaya, 1964, hal. 16; Bidari, 1996, hal. 16; Santina, 1997, hal. 161).

3. Lotus (Nelumbo nucifera Gaertn). Tanaman ini muncul dalam kisah kelahiran Buddha. Setelah Buddha lahir, dia berjalan tujuh langkah, dan bunga lotus mekar di tempat dia menginjakkan kakinya (Weise, 2013, hal. 52; Hong dan Joo, 2017, hal. 246)

4. Mangga (Mangifera indica). Pohon mangga banyak ditemukan dalam relief di Candi Borobudur. Beberapa literatur dan panil relief menyebutkan bahwa tanaman ini merupakan salah satu tanaman yang berasosiasi dengan Buddha, seperti tentang penggambaran kelahiran Sang Buddha di bawah pohon mangga, persembahan hutan mangga (Amravati) pada Sang Buddha saat berkunjung ke Vaisali, pembelian hutan dimana digambarkan ada pohon mangga,oleh Anathapindika yang ingin disumbangkan kepada Buddha Sakyamuni dan pengikutnya, serta masih ada beberapa kisah tentang pohon mangga lainnya (Bidari, 1996, hal. 18). 
Setelah mengetahui jenis tanaman dan fungsinya dalam konteks bangunan suci atau candi sebagaimana diuraikan di atas, tentunya hasil kajian ini perlu dimanfaatkan. Salah satu caranya adalah dengan menggunakan jenis-jenis tanaman tersebut sebagai elemen pembentuk lanskap di lingkungan candi yang masih ada di kawasan Candi Borobudur. Hasil kajian ini dapat dipakai dalam penataan kawasan Candi Borobudur yang kini semakin berubah. Penataan lanskap yang diilhami oleh suasana yang tergambarkan pada relief Candi Borobudur barangkali akan dapat memberikan suasana yang khas dan memberikan pengalaman yang berkualitas bagi pengunjung. Setidaknya, mereka akan merasakan kembali ke suasana di masa pembangunan candi ini. Selain itu, penataan dengan kearifan di masa lampau akan membantu mempertahankan lingkungan pedesaaan lebih baik dan sehat sebagaimana diharapankan dalam pengelolaan Kawasan Warisan Dunia Candi Borobudur.

\section{KESIMPULAN}

Pembahasan dalam tulisan ini telah menunjukkan hanya jenis-jenis tanaman tertentu saja yang digambarkan pada lingkungan candi atau bangunan suci, sehingga dapat diketahui jenis pohon apa yang cenderung dipilih sebagai pembentuk lanskap bangunan suci atau candi. Sebagai elemen pembentuk lanskap, rupanya jenis tanaman itu setidaknya mempunyai utama sebagai peneduh dan penghias halaman. Namun demikian, ternyata ditemukan juga jenis pohon yang dapat dipakai sebagai pohon permintaan atau harapan (wishing tree). Pada penelitian ini jenis pohon bodhi dan dadap difungsikan sebagai pohon pengabul permintaan tersebut. Dengan demikian, fungsi pohon tidak terbatas sebagai elemen lanskap tetapi juga memiliki fungsi simbolik religious.

Hasil identifikasi pada relief Karmawibhangga, Lalitavistara, dan Jataka-Avadana (b) ditemukan sekitar 24 unit bangunan suci/candi yang memiliki halaman dengan tanaman sebagai latar belakangnya berjumlah 47 tanaman. Jenis tanaman yang berhasil diidentifikasi dari 47 tanaman tersebut sebanyak 20 jenis tanaman yang terdapat pada 33 tanaman. Terdapat sebanyak 14 tanaman yang belum berhasil diidentifikasi. Tanaman yang memiliki fungsi sebagai peneduh ada 11 jenis yaitu angsana, beringin cina, bodhi, duku, jambu air, karet merah/karet kebo, keben, ketapang, mangga, nyamplung, dan sukun. tanaman yang memiliki fungsi sebagai penghias ada 8 jenis yaitu asoka, damar, kecubung, kelapa, lontar, lotus, pisang, dan teratai. Ada pula satu jenis tanaman yang dapat berfungsi sebagai peneduh karena memiliki tajuk yang lebar dan rindang namun dapat juga berfungsi sebagai penghias karena memiliki bunga yang indah yaitu tanaman dadap.

Penelitian lanjutan masih perlu dilakukan untuk melengkapi hasil kajian yang sudah dilakukan hingga saat ini. Masih ada sejumlah relief yang selama ini belum dikaji secara tuntas, sehingga masih perlu untuk ditelaah lebih lanjut. Meskipun demikian, harus diakui mungkin ada sejumlah kendala yang dihadapi dalam proses identifikasi jenis tanaman. Hal ini disebabkan oleh cara pandang masing-masing peneliti saat mengkaji karakter jenis tanaman yang tergambar pada relief. Beberapa karakter jenis tanaman memiliki bentuk yang hampir sama sehingga hal tersebut dapat membingungkan dalam pemilihan jenis tanaman yang tepat. Selain itu, penggambaran yang dilakukan oleh para silpin pada relief, umumnya tidak menggunakan skala yang sama, sehingga hal tersebut juga menyulitkan perbandingan dengan jenis tanaman aslinya. Namun, dengan kemajuan ilmu pengetahuan dan teknologi, barangkali kendala akan dapat diatasi atau setidaknya di kurangi. 


\section{DAFTAR PUSTAKA}

Abhinav, M. C. et al. (2018) "Impact of rainfall on the coconut productivity in Kozhikode and Malappuram Districts of Kerala," Current Agriculture Research Journal, 6(2), hal. 183-187. doi: 10.12944/carj.6.2.07.

Atmadi, P. (1979) Beberapa Patokan Perancangan Bangunan Candi: Suatu Penelitian Melalui Ungkapan Bangunan pada Relief Candi Borobudur, Pelita Borobudur Seri C No. 2. Proyek Pelita Pemugaran Candi Borobudur Departemen Pendidikan dan Kebudayaan.

Bidari, B. (1996) "Forests and Trees Associated with Lord Buddha," Ancient Nepal. Kathmandu: Department of Archaeology, 139, hal. 11-24.

Brink, R. C. B. Van Den (1931) "Welke Planten Vindt Men op de Boroboedoer Afgebeeld?,” De Tropische Natuur.

Cammerloher, H. (1931) "Wat de Boroboedoer Den Natuuronderzoeker Leert," De Tropische Natuur.

Committee, W. H. (2012) Convention Concerning the Protection of The World Cultural and Natural Heritage. Saint Petersburg.

Cunningham, A. (1892) Mahabodhi: The Great Buddhist Temple. London: W.H Allen \& Co.

Dwiyani, R. (2013) Mengenal Tanaman Pelindung di Sekitar Kita. Denpasar: Udayana University Press.

Ferrari, F. M. dan Dahnhardt, T. W. P. (ed.) (2016) Roots of Wisdom, Branches of Devotion; Plant Life in South Asian Traditions. Bristol: Equinox Publishing Ltd.

Hakim, R. dan Utomo, H. (2004) Komponen Perancangan Arsitektur Lansekap : Prinsip Unsur dan Aplikasi Disain. Cetakan ke. Jakarta: Penerbit Bumi Aksara.

Hari Setyawan et al. (2018) Laporan Kajian Klasifikasi dan Analisis Kontekstual Jenis Tanaman pada Relief Candi Borobudur. Magelang.

Hong dan Joo, E. (2017) "Lotus: Symbol of Rebirth and Resurrection,” Eurasian Journal of Analytical Chemistry, 12, hal. 1-8.

Jayakumar, K. (2019) "Traditional uses of Sthalavriksham in and around Lord Siva Temple, Mayiladuthurai, Southern India,” 128(April), hal. 88-109.

Joshi, N. C., Chaudhary, A. dan Rawat, G. S. (2018) "Cheura (Diploknema butyracea) as a livelihood option for forest-dweller tribe (Van-Raji) of Pithoragarh, Uttarakhand, India," ESSENCE International Journal for Environmental Rehabilitation and Conservation, 9(1), hal. 134-141. doi: 10.31786/09756272.18.9.1.116. 
Krom, N.J. (1927) Barabudur, Archaeological Description, Volume II. Leyden: The Hague.

Kumar, N. et al. (2020) "Role of Ethnic and Indigenous People of North Western Himalayan Region of Himachal Pradesh in the Conservation of Phyto- Diversity Through Religious and Magico-Religious Beliefs.," International Journal of Creative Research Thoughts (IJCRT), 8(7), hal. 1846-1855.

Lestari, G. dan Kencana, I. P. (2015) Tanaman Hias Lanskap. Edisi Revi. Jakarta: Penebar Swadaya.

Metusala, D. et al. (2020) "The identification of plant reliefs in the Lalitavistara story of Borobudur temple, central Java, Indonesia,” Biodiversitas, 21(5), hal. 2206-2215. doi: 10.13057/biodiv/d210549.

Munandar, A. A. (2018) Antarala Arkeologi Hindu-Buddha. Jakarta: Penerbit Wedatama Widya Sastra.

Puspitasari, D. E., Setyawan, H. dan Rini, W. D. P. (2010) Kearsitekturan Candi Borobudur. Magelang: Balai Konservasi Peninggalan Borobudur.

Raut, P., Nayak, S. V. dan Gotmare, S. R. (2017) "Bombax Ceiba: Kalpataru, a Tree of Life.," International Journal of Advanced Research, 5(2), hal. 1211-1214. doi: 10.21474/ijar01/3273.

Santiko, H. (2012) Relief Karmawibhangga :Identifikasi Adegan dan Ajaran Hukum Karma, Adegan dan Ajaran Hukum Karma pada Relief Karmawibhangga, Adegan dan Ajaran Hukum Karma pada Relief Karmawibhanga. Magelang: Balai Konservasi Borobudur.

Santina, P. Della (1997) The Tree of enlightenment: An Introduction to the Major Traditions of Budhism. Chico: Chico Dharma Study Foundation.

Sarwono, E. (1985) Flora pada Relief Karmawibhangga Candi Borobudur. Universitas Indonesia.

Sedyawati, E. (2011) "Ikonografi Barabudur," in 100 Tahun Pemugaran Candi Borobudur, Trilogi I : Menyelamatkan Kembali Candi Borobudur. Magelang: Balai Konservasi Borobudur, hal. 37-41.

Soekmono (1976) Chandi Borobudur, A Monument of Mankind. Edisi I, Chandi Borobudur. Edisi I. Paris: The Unesco Press.

Steinmann, A. (1934) “De op de Boroboedoer Afgebeelde Plantenwereld,” Tijdschrift Voor Indische Taal-Land- En Volkenkunde. Koninklijk Bataviaasch Genootshap van Kunsten en Wetenschappen, LXXIV.

Stutterheim, W. (1989) Rama-Legends and Rama-Reliefs in Indonesia. New Delhi: Indira Gandhi National Centre for the Arts.

Suhartono, Y. et al. (2017) Borobudurpedia. Magelang: Balai Konservasi Borobudur. 
Upadhyaya, K. D. (1964) “Indian Botanical Folklore,” Asian Folklore Studies. Nagoya: Nanzan University, 23, hal. 15-34.

Weise, K. (ed.) (2013) The Sacred Garden of Lumbini: Perceptions of Buddha's birthplace. Paris: United Nations Educational, Scientific and Cultural Organization.

Widyastuti, T. (2018) "Teknologi Budidaya Tanaman Hias Agribisnis.” Bantul: CV Mine, hal. 1-228. 